\title{
Isolation and Purification of Microbial Glucan sucrase from Decayed Tooth extracts
}

\author{
Polampalli Phani Deepika ${ }^{1}$, Dr. D.Sudheer kumar ${ }^{2}$, Prof M.Lakshmi Narasu³, \\ Dr.P.Srinivas ${ }^{4}$ \\ ${ }^{1}$ Assistant Professor. Care college of pharmacy, Oglapur, Warangal.Telangana. \\ ${ }^{2}$.HOD, Department of pharmaceutics. Care college of pharmacy.Oglapur.Warangal.Telangana \\ ${ }^{3}$ Professor, Centre for biotechnology, IST, JNTU.Hyderabad, Telangana.. \\ ${ }^{4}$ Assistant Professor.Department of Biotechnology, NIT, Warangal,Telangana.
}

\begin{abstract}
The present objective of the research work is isolation of glucan sucrase from the decayed tooth extracts by carrying out inoculation of dental samples into Todd-Hewitt broth and centrifugation. The culture supernatant is subjected to protein fractionation and supernatant collected is purified for the enzyme by anion exchange chromatography and gel permeation. The solution from the above purification procedures are finally subjected to electrophoresis using SDS-PAGE. Molecular weight bands are compared and the glucan sucrase analysed from purified band.
\end{abstract}

Key words: Tooth decay extracts, Fractionation, Gel permeation, Ion exchange chromatography, PAGE electrophoresis

\section{Introduction}

Enzymes are extremely selective catalysts.They are specific for the type of reaction catalyzed and for a single substrate.They are stereo specific. (Leninger). They have the capability to bind in three points and hence convert nonchiral substrate to chiral products.Enzymes are important practical tools in medicines and chemical industry.Enzymes from different tooth decay samples constitute amylases,glucan sucrases,levan sucrases,invertases. In humans dietary sugar intake has been well established in facilitating onset of dental infections, one of the most common type of bacterial infection.Glucan sucrases are examples of bacterial enzymes acting on carbohydrates. They are relatively large extracellular enzymes. Based on four catalytically consumed sequence motifs glucan sucrases have been classified as members of glycoside hydrolase family GH70. .Different microorganism species like Streptococcus, Leuconostoc, Lactobacillus are producers of glucan sucrase. (Banas and Vickermann) Several methods are employed for glucan sucrase purification and characterization in terms of molecular weight. Purification techniques like protein fractionation, chromatography techniques, gel electrophoresis are employed in present research work.(R.Shukla and Goyal) Glucan sucrase is obtained from supernatant. Protein concentration is determined by assays.

\section{Materials And Methods}

All the materials and chemicals used in present research work are procured from Himedia laboratories and S.D.Fine chemicals.

\section{Sample collection and culture conditions maintenance}

Different decayed tooth are collected from kakatiya dental clinic in Warangal .They are dissolved in diluted acetone solution. This sample of decayed tooth extracts dissolved in Todd Hewitt broth and incubated for $48 \mathrm{hrs}$ at $37^{\circ} \mathrm{c}$.After incubation the culture is centrifuged at $12000 \mathrm{rpm}$ for $30 \mathrm{~min} .80 \mathrm{ml}$ of the supernatant is collected and enzyme activity is determined. The same supernatant is used for protein fractionation

\section{Proten Fractionation By Ammonium Sulphate Precipitation}

To $80 \mathrm{ml}$ of supernatant $31.6 \mathrm{gms}$ of ammonium sulphate is added and incubated overnight. After incubation the supernatant is again centrifuged at $12000 \mathrm{rpm}$ for $30 \mathrm{~min}$.Both pellet and supernatant is collected. The pellet is dissolved in minimum amount i.e., $25 \mathrm{ml}$ of Tris buffer and dialysis is carried by Tris-Hcl buffer for $24 \mathrm{hrs}$.The sample is collected and assayed for protein. The supernatant is collected and $39.2 \mathrm{gms}$ of ammonium sulphate is added and centrifuged. After centrifugation the sample is assayed for protein concentration using GOPOD assay.(Veselin Bivolarski et al) 


\section{ION EXCHANGE CHROMATOGRAPHY}

The protein sample collected from above fractionation is loaded in anion exchange chromatography of Acta prime system having UV detector with coloumn Q sepharose matrix. Sodium phosphate buffer of $\mathrm{pH} 8.0$ is used having Buffer A and Buffer B is $0.5 \mathrm{M}$ sodium chloride. The flow rate is $1 \mathrm{~min} / \mathrm{ml}$ and pressure maintained at $0.3 \mathrm{Mpa}$.

\section{Procedure}

The mobile phase is drained at the top of the column packing till the bed surface gets exposed. The outlet is closed and the sample is gently applied uniformly over the bed surface with pipette and the loaded sample is allowed to just enter into the column by opening the outlet. A small amount of mobile phase is added to wash the traces of the sample into the column. After sufficient amount of buffer at the top of the column is added it is connected to reservoir. Fractions of sample is collected at eluting peak and the protein concentration is determined

\section{GEL PERMEATION CHROMATOGRAPHY}

Gel filtration is carried out for $2.5 \mathrm{ml}$ of fractionated protein sample in Actaprime system and detected by UV detector by using the column DEAE Sepharose and sodium phosphate $\mathrm{pH} 8$ buffer at a flow rate of $1 \mathrm{ml}$ /min and 0.3megapascal pressure.

\section{Procedure}

The mobile phase is drained out till the bed surface gets exposed and the outlet is closed. The sample is applied gently over the bed surface with pipette and the loaded sample is allowed to just enter the coloumn by opening the outlet. Traces of sample are washed with adding small amount of mobile phase. Sufficient amount of buffer is added on the top of the column and connected to the buffer reservoir. Fractions of the sample are collected at the eluting peak and the protein is measured

\section{Bradford assay method}

Reagents-standard stock solution $(1 \mathrm{mg} / \mathrm{ml})$ prepared by dissolving $100 \mathrm{mg}$ of lysozyme to $100 \mathrm{ml}$ of distilled water. Working standard solution $(1 \mu \mathrm{g} / \mathrm{ml})$ prepared by diluting $10 \mathrm{ml}$ of stock to $100 \mathrm{ml}$ of distilled water .Bradford reagent: Coomassie brilliant blue G-250 dissolved in $99 \%$ ethanol and made up to $100 \mathrm{ml}$ by $85 \%$ phosphoric acid. The protein molecules bind to coomassie dye under acidic conditions and results in change of color from brown to blue.10, 20,30,40,50 $\mu$ l of protein solution from the stock solution are taken in different test tubes and the volume in each tube is made to $2 . \mathrm{ml}$ with distilled water. $1 \mathrm{ml}$ of Bradford reagent is added to each tube and contents are mixed well. The tube is allowed to stand for 30min at room temp .Absorbance is measured at $595 \mathrm{~nm}$ by using Elico Spectrophotometer (Table 1). A blank is kept simultaneously which contains $6 \mathrm{ml}$ of distilled water instead of protein solution. A graph is plotted b/n conc. of protein vs. absorbance.Caluculation: A calibration graph is constructed by taking standard conc on $\mathrm{X}$-axis and absorbance at $595 \mathrm{~nm}$ on y-axis. (Fig 3) Unknown concentration is computed by formula.

Test $=($ Absorbance of Test /absorbance of standard $) \times$ standard conc

\section{ELECTROPHORESIS BY SDS-PAGE}

Different samples are collected after protein fractionation and chromatography techniques and crude samples are loaded in vertical gel electrophoresis and different molecular weight bands are studied for the protein sample.(Shimamura et al) Seperating Gel $12 \%$ is used which is made of distilled water $30 \%$ acrylamide (4ml ) $1.5 \mathrm{M}$ Tris $\mathrm{pH} 8.8(2.5 \mathrm{ml}) 10 \%$ SDS W/V $(100 \mu \mathrm{l}) \quad 10 \%$ APS w/v $(100 \mu \mathrm{l})$ and $4 \mu \mathrm{l}$ TEMED is used. Stacking Gel (5\%) is used which is prepared by $2.76 \mathrm{ml}$ of distilled water, $0.66 \mathrm{ml}$ of $30 \%$ acryl amide and $2.5 \mathrm{ml}$ of $6.8 \mathrm{pH} 0.5 \mathrm{Mm}$ Tris and $40 \mu \mathrm{l}$ of $10 \%$ SDS w/v,30 $\mu \mathrm{l}$ of $10 \%$ APS $w / \mathrm{v}$ and $15 \mu \mathrm{l}$ of TEMED .

Buffers : 4x Sample buffer $5 \mathrm{ml}$ is used which has $1.15 \mathrm{ml}$ of Tris $1 \mathrm{M}$ w/v ,glycerol (v/v) $1.5 \mathrm{ml}$,.bromophenol blue w/v $0.002 \mathrm{~g}$ and $2 \mathrm{ml}$ of $20 \%$ SDS w/v, 20 $\mu$ l of $\beta$ mercaptoethanol. 5x SDS running buffer is used containing Tris HCL, Glycine and 10\% SDS. Staining solution Coomassie brilliant blue G-250 and methanol: acetic acid: water 4:1:5 is used and destaining solution has only methanol; acetic acid and water. The spacers were placed in between the glass and ceramic plate and fixed. First the separating gel was prepared by adding all chemicals and at last APS and TEMED was added and was loaded. Ammonium per sulphate forms a free radical which initiates the polymerization of Acrylamide.Bisacrylamide forms polymerization, the cross linking of acryl amide.TEMED stabilizes free radicals and improves. After loading separating gel few $\mathrm{ml}$ of water or Isopropanol was added to remove any air bubbles and for even distribution of the gel. After solidification water was drained off and 5\% stacking gel was added and comb was placed. The comb was removed after solidification and wells were ready to use. $30 \mu \mathrm{l}$ of sample was taken and $10 \mu \mathrm{l}$ of SDS sample buffer was added and vortexed.Then the samples were kept in boiling water bath at $95^{\circ} \mathrm{C}$ temperature for 3 minutes and 
the samples were loaded onto SDS-PAGE along with a molecular weight marker.Color protein Molecular weight marker was used and the range was 55 to $170 \mathrm{kD}$.The apparatus was connected to power pack with $25 \mathrm{~mA}$ and the gel was allowed to run, until $1 \mathrm{~cm}$ was left.The power supply was stopped and the gel was removed and kept for staining. After staining overnight gel was destained and the gel was observed.(fig 4)

\section{Results Ad Discussion}

The supernatant culture solution after protein fractionation is tested for presence of the enzyme. The solution is tested for glucose release which is activity of sucrolytic enzyme. Enzyme releases glucose which is oxidized by glucose oxidase producing gluconate and hydrogen peroxide. Hydrogen peroxide is then oxidatively coupled to 4 amino antipyrene and phenol in the presence of peroxidase to yield red quinoemine dye measured at 505.Absorbance is directly proportional to concentration of glucose. Enzyme activity is found by releasing $85 \mathrm{mg} / \mathrm{dl}$ of glucose before ammonium sulphate precipitation and $92 \mathrm{mg} / \mathrm{ml}$ of glucose after ammonium sulphate precipitation.The peak of the supernatant sample is eluted after $35 \mathrm{~min}$ of buffer flow rate in gel permeation chromatography (Fig 2). Flow rate of the buffer is $4-5 \mathrm{ml} / \mathrm{min}$ where the conductivity decreased and sample solution is collected and tested for protein concentration by Bradford assay method (Table 1) which is $0.17 \mathrm{mg} / 50 \mu \mathrm{l}$ of sample volume. The anion exchange column resulted the peak at $4-7 \mathrm{ml} / \mathrm{min}$ of Nacl flow in QSepharose coloumn.After 20min the sample injected into column which has shown peak in fig(1).The protein from sample collected is found to have $155 \mu \mathrm{g} / 50 \mu \mathrm{l}$ from Bradford assay. The sample solutions from ammonium sulphate precipitation, gel permeation, and ion exchange chromatography are analyzed by SDS-PAGE for the purification and molecular weight determination of the protein purified shown in fig 4.The molecular weight is reported to be in between $150 \mathrm{kDa}$ to $170 \mathrm{kDa}$.

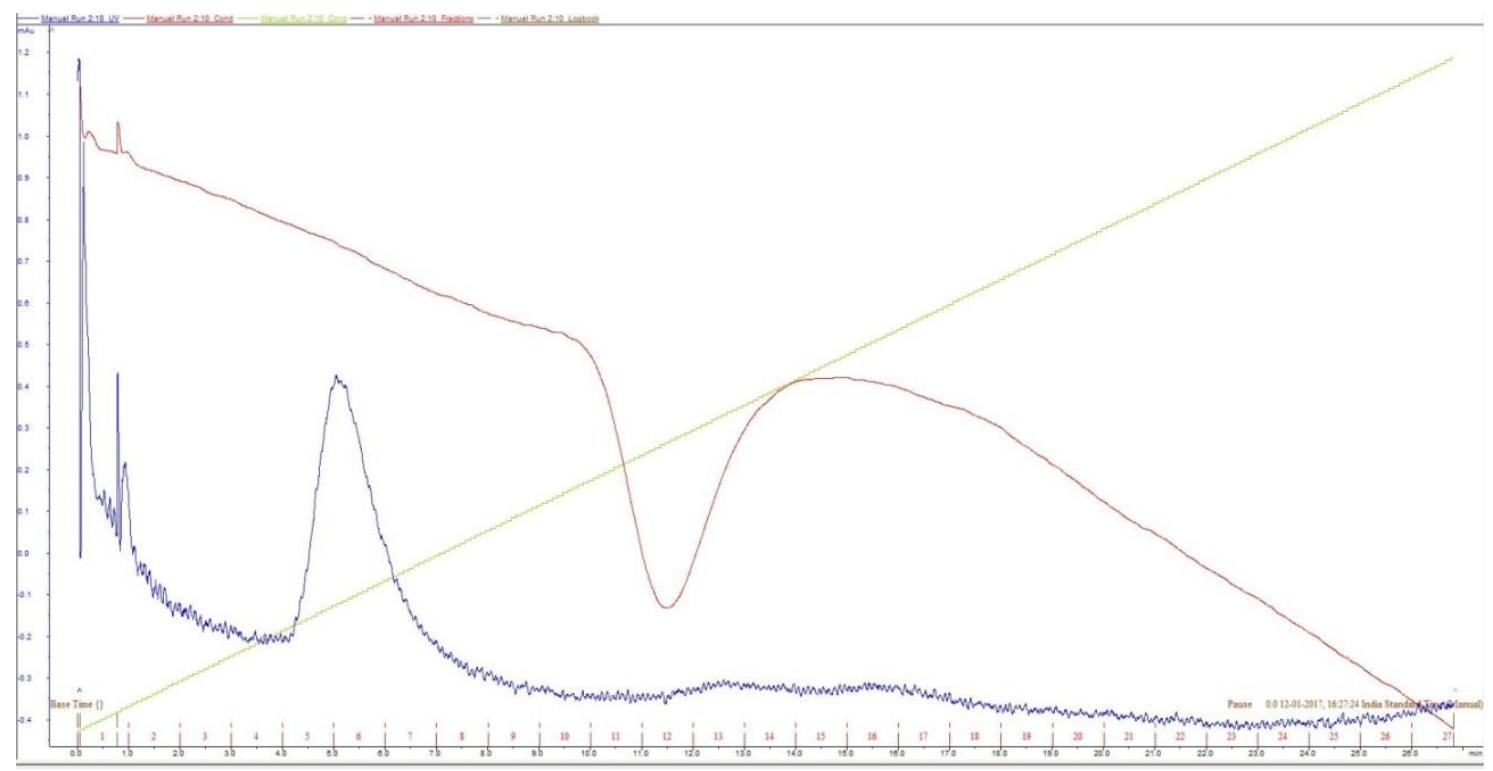

Figure 1: Ion Exchange Chromatography

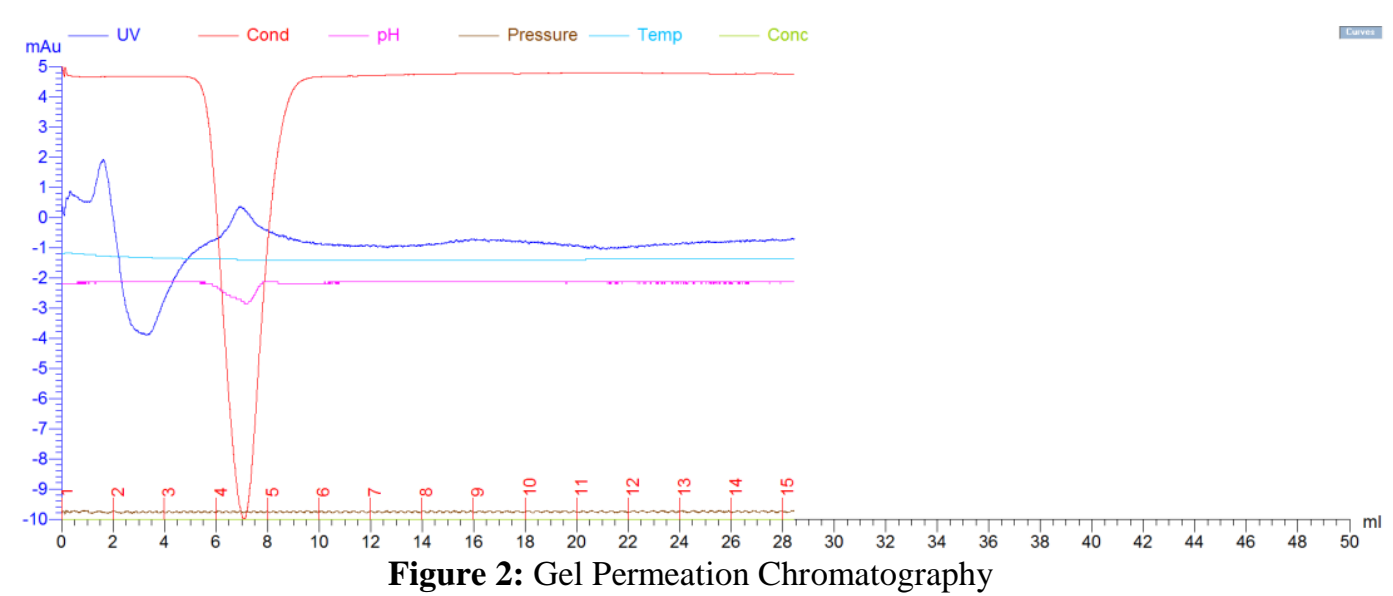


Bradford assay absorbance values and calculation of concentration of protein

Table 1:

\begin{tabular}{|c|c|c|c|c|c|}
\hline S.no & Vol of lysozyme (mL) & $\begin{array}{c}\text { Vol of water in } \\
(\mathrm{mL})\end{array}$ & $\begin{array}{c}\text { Conc of protein } \\
(\mu \mathrm{g} / \mathrm{mL})\end{array}$ & $\begin{array}{l}\text { Vol of Bradford } \\
\text { reagent }(\mathrm{mL})\end{array}$ & O.D at 595nm \\
\hline 1 & 0.1 & 0.9 & 100 & 1 & 0.062 \\
\hline 2 & 0.2 & 0.8 & 200 & 1 & 0.131 \\
\hline 3 & 0.3 & 0.7 & 300 & 1 & 0.216 \\
\hline 4 & 0.4 & 0.6 & 400 & 1 & 0.301 \\
\hline 5 & 0.5 & 0.5 & 500 & 1 & 0.356 \\
\hline 6 & 0.6 & 0.4 & 600 & 1 & 0.405 \\
\hline 7 & 0.7 & 0.3 & 700 & 1 & 0.441 \\
\hline Unknown sample & $0.50 \mu 1$ & $950 \mu 1$ & $5 \mu \mathrm{g}$ & 1 & 0.112 \\
\hline
\end{tabular}

Protein concentration from anion exchange chromatograph=

(OD OF TEST VALUE/O.D OF STANDARD) x STANDARD PROTEIN CONC.

$=0.112 / 0.216 \times 200$

$=155 \mu \mathrm{g} / 50 \mu \mathrm{l}$

Protein concentration from gel permeation chromatography $=.0 .112 / 0.131 \times 200=170.99 / 50 \mu \mathrm{L}$

Fig 3

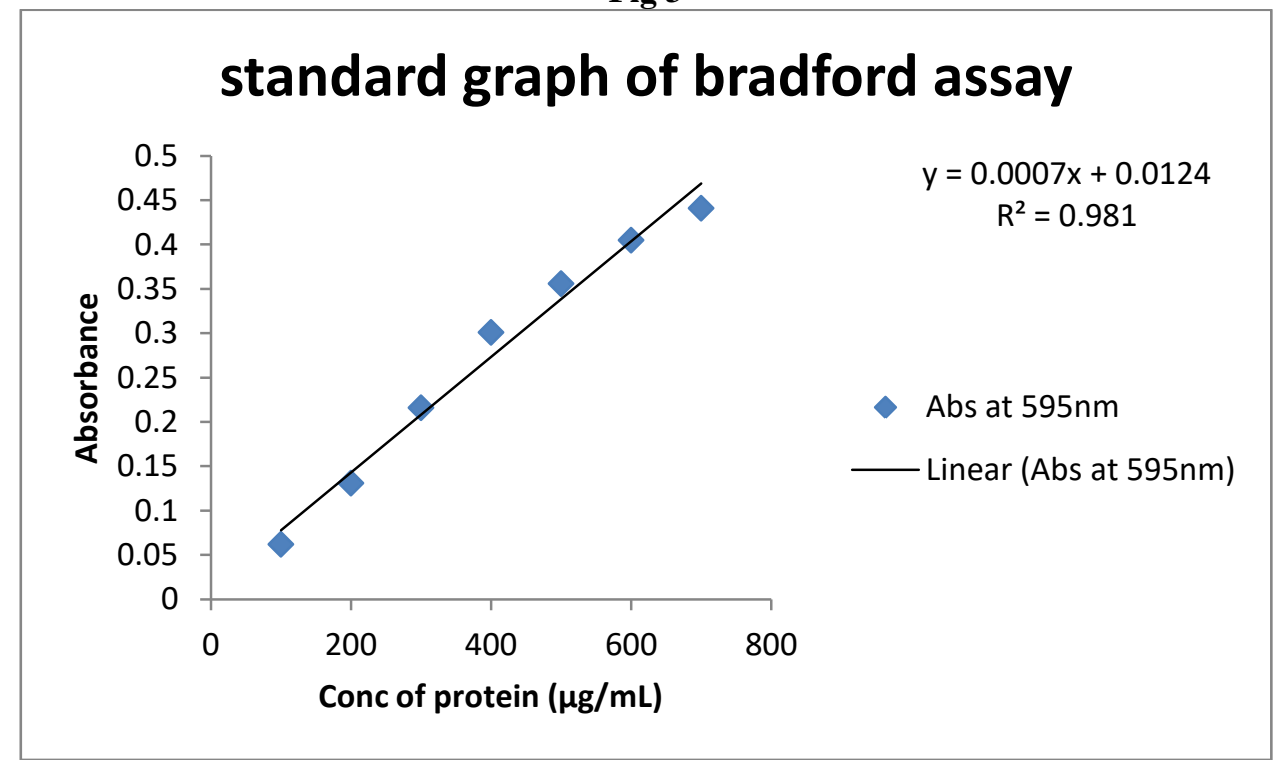

Figure 4: SDS PAGE of the protein samples

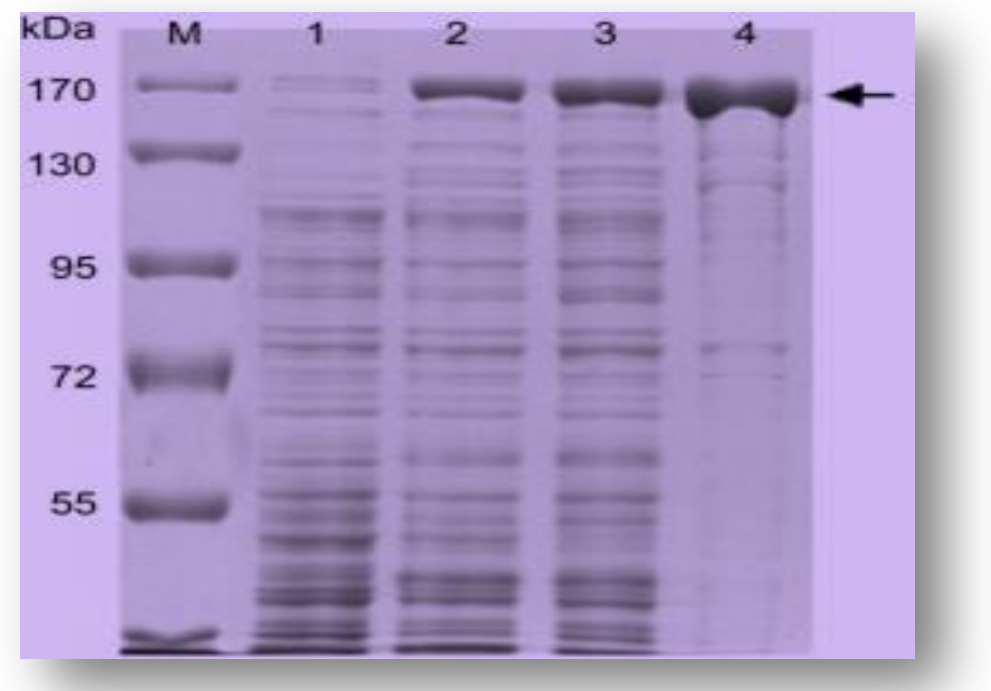

$1=$ sample collected after gel permeation, 2= sample after ammonium sulphate precipitation, $3=$ sample after ammonium sulphate precipitation, 4=sample after ion exchange chromatography 


\section{Acknowledgement}

I sincerely thank research scholars of NIT, Warangal and lab technicians of Care college of pharmacy for providing good platform and assisting in my research work

\section{References}

[1]. Banas, J.A. \& Vickermann, M.M. 2003, "Glucan-binding proteins of the oral streptococci", Critical reviews in oral biology and medicine : an official Publication of the American Association of Oral Biologists, vol. 14, no. 2, pp. 89-99.

[2]. Chassy B.M 1976 A gentle method for the lysis of oral Streptococci. Biochem Biophys Res commun 69; 603-608.

[3]. Hendrick Hellmuth, Sabine wittrock, slavko kralj. Engineering the glucan sucrase GTFR enzyme reaction amd glycosidic bond specificity toward tailor made polymer and oligosaccharide products. Biochemistry 2008, 47, 6678-6684.

[4]. Keevil.C, A. West, P.Marsh, and D.C Ellwood. 1983 Batch versus continuous culture studies of glucosyl transferase synthesis in oral streptococci. P. 189-200.

[5]. Lehninger, A.L., Nelson, D.L. and Cox, M.M (2004) Lehninger Principles of biochemistry, (4 ${ }^{\text {th }}$ edition); W.H. Freeman\&co; Newyork, USA. 191-225.

[6]. Majumder, A.Mangtani A \&Goyal A. Purification, identification and functional characterization of glucan sucrase from Leuconostoc dextranium NRRL. B1146, current trends Biotechnol pharm, 2(2008) 493.

[7]. Monchois V., Willemot R, M.Monsan P(1999)Glucan sucrases mechanism of action and structure function relationships. FEMS microbial Rev 23;131-151.

[8]. R.Shukla .I. ILiev and A.Goyal.Purification and characterization of dextran sucrase from Leuconostoc mesenteroides NRRLB1149. Biotechnical. Special edition pg .576-578

[9]. Shimamura A; Tsumori, Mukasa H(1982) Purification ad properties of Streptococcus mutans extracellular glucosyl transferase biochem biophys. Acta 702, 72-80.

[10]. Veselin Bivolrski,Tonka Vesileva,Balik Dzhambazov,Albena manchilova.Jean-mare chobert,Iskra ivanova and ilia lliev (2013).Charecterization of Glucan sucrases and Fructan sucrases produced by wild strains Leuconostoc mesenteroides URE 13 and Leuconostoc mesenteroides LM17 Grown on Glucose or Fructose medium as sole carbon source, Biotechnology and Biotechnological equipment, 27:3,3811-3820.

[11]. U.K Laemmli, Nature, 227 pp 32-100 gel electrophoresis of glucan sucrase. 